\title{
HUBUNGAN KUALITAS TIDUR DENGAN PENINGKATAN TEKANAN DARAH PADA LANSIA DI UNIT PELAYANAN SOSIAL LANJUT USIA PUCANG GADING KOTA SEMARANG
}

\author{
Ni. Nyoman Maryaningtyas Adinatha ${ }^{1}$, Indah Wulaningsih ${ }^{2}$, Hadi Suryanto ${ }^{3}$ \\ STIKes Karya Husada Semarang \\ Email: adinatha_arraafi@yahoo.com
}

\begin{abstract}
ABSTRAK
Hipertensi merupakan salah satu penyakit degeneratif. Umumnya tekanan darah bertambah secara perlahan dengan bertambahnya umur. Ketidakcukupan kualitas dan kuantitas tidur dapat merusak memori dan kemampuan kognitif. Bila hari ini berkelanjutan hingga bertahun-tahun, akan berdampak pada tekanan darah tinggi. Untuk mengetahui hubungan kualitas tidur dengan peningkatan tekanan darah pada lansia di Unit pelayanan lanjut usia Pucang Gading Kota Semarang. Jenis penelitian ini kuantitatif desain cross sectional. Tehnik purposive sampling Sample penelitian 48 responden uji statistik Chi-Square. Dalam penelitian ini kualitas tidur baik sebagian besar mempunyai tekanan darah pre hipertensi sebanyak 14 responden $(63,6 \%)$ dan yang mempunyau kualitas tidur buruk sebagian besar mempunyai tekanan darah hipertensi sebanyak 19 responden $(73,1 \%)$. Ada hubungan antara kualitas tidur dengan peningkatan tekanan darah di Unit pelayanam sosial lanjut usia Pucang Gading Kota Semarang, dengan $\mathrm{p}$ value $0,000<0,05$.
\end{abstract}

Kata kunci : Kualitas Tidur, Tekanan Darah, Lansia 


\title{
CORRELATION OF SLEEPING QUALITY WITH BLOOD PRESSURE IN ELDERLY IN THE CONTINUOUS SOCIAL SERVICE UNIT OF PUCANG GADING AGE, SEMARANG CITY
}

\begin{abstract}
Hypertension is a degenerative disease. Generally blood pressure increases slowly with age. Insufficient quality and quantity of sleep can damage memory and cognitive abilities. If today continues for years, it will have an impact on high blood pressure. To determine the relationship between sleep quality and increased blood pressure in the elderly in the elderly service unit of Pucang Gading, Semarang City. This type of research is quantitative cross sectional design. Purposive sampling technique Research sample 48 respondents Chi-Square statistical test. Good sleep quality mostly had pre hypertension blood pressure as many as 14 respondents (63.6\%) and those with poor sleep quality mostly had hypertension blood pressure as many as 19 respondents (73.1\%). There is a relationship between sleep quality and elevated blood pressure in the elderly social care unit of Pucang Gading, Semarang City, with a $p$ value of $0.000<0.05$.
\end{abstract}

Keywords : Sleep Quality, Blood Pressure, Elderly 


\section{PENDAHULUAN}

Lanjut usia merupakan bagian dari tumbuh kembang manusia. Manusia tidak secara tiba-tiba menjadi tua, tetapi berkembang dari bayi, anak-anak, dewasa, dan akhirnya menjadi tua. (Azizah, M. Lilik, 2011). Masa lansia adalah masa perkembangan terakhir dalam hidup manusia. Perubahan fisik lansia pada sistem kardiovaskuler akan berpengaruh terhadap tekanan darahnya. Dalam hal ini dapat terjadi hipertensi (Triyanto, 2014).

Hipertensi hampir disetiap
negara menduduki peringkat pertama
sebagai penyakit yang paling sering
dijumpai. Secara global data World
Health Organization menunjukkan, diseluruh dunia sekitar 1 miliar orang angka ini kemungkinan akan meningkat menjadi $50 \%$ ditahun 2025, dari 1 miliar pengidap hipertensi, $33,3 \%$ berada dinegara maju dan $66,7 \%$ sisanya berada dinegara sedang berkembang termasuk Indonesia.

Berdasarkan data WHO pada tahun 2014 terdapat sekitar 600 juta penderita hipertensi diseluruh dunia. Prevalensi tertinggi terjadi di wilayah Afrika yaitu sebesar 30\%. Prevalensi terendah terdapat diwilayah amerika sebesar 18\%. Secara umum, laki-laki memiliki prevalensi hipertensi yang lebih tinggi dibandingkan wanita.

Hipertensi merupakan salah satu penyakit degeneratif. Umumnya tekanan darah bertambah secara perlahan dengan bertambahnya umur. Risiko untuk menderita hipertensi pada populasi $\geq 55$ tahun yang tadinya tekanan darahnya normal adalah $90 \%$. Kebanyakan pasien mempunyai tekanan darah pre hipertensi sebelum mereka di diagnosis dengan hipertensi, dan kebanyakan diagnosis hipertensi terjadi pada umur diantara dekade ketiga dan dekade kelima[4].

Menurut Dinas Kesehatan Kota Semarang, prevalensi hipertensi di Rumah Sakit dan di Puskesmas Kota Semarang pada tahun 2017, yaitu hipertensi essensial 29.335 orang dan hipertensi lain 1.247 orang, sedangkan Jumlah kematian penyakit hipertensi di Rumah Sakit dan Puskesmas Semarang, yaitu hipertensi esensial 50 orang hipertensi lain 28 orang.

Kebutuhan waktu tidur bagi setiap orang berlainan, tergantung pada kebiasaan yang dibawa selama perkembangannya menjelang dewasa, aktifitas pekerjaan, usia dan kondisi kesehatan. Kebutuhan tidur pada usia lanjut 5-8 jam untuk menjaga kondisi fisik karena usia yang semakin senja mengkibatkan sebagian anggota tubuh tidak dapat berfingsi optimal, maka untuk mencegah adanya penurunan kesehatan dibutuhkan energi yang cukup dengan pola tidur yang sesuai.(Ardiansyah, 2012)

Ketidakcukupan kualitas dan kuantitas tidur dapat merusak memori dan kemampuan kognitif. Bila hari ini berkelanjutan hingga bertahun-tahun, akan berdampak pada tekanan darah tinggi, serangan jantung, stroke hingga masalah psikologis seperti depresi dan gangguan perasaan lain. Apakah hal ini 
berlangsung dalam waktu yang lama, akan menyebabkan individu tersebut mengalami kurang tidur yang mengakibatkan peningkatan resiko penyakit yang dideritanya (Madyo, 2014)

Berdasarkan penelitian yang dilakukan Riska Havisa, Sugianto (2014) tentang hubungan kualitas tidur dengan tekanan darah penderita pada

\section{METODE PENELITIAN}

Metode penelitian ini merupakan penelitian kuantitatif dengan deskriptif korelasional yang menggunakan desain cross sectional. Penelitian deskriptif korelatif yaitu suatu metode penelitian dengan cara menelaah hubungan antara dua variabel pada suatu situasi atau sekelompok subjek. Hal ini dilakukan untuk melihat hubungan antara gejala satu dengan yang lain, atau variabel satu dengan variabel yang lain dengan metode usia lanjut di posyandu lansia dusun Jelavan Sundumartani Ngemplak Sleman didapat jumlah penduduk lansia mengeluh sering terbangun pada malam hari dan setelah itu sulit untuk tertidur kembali, dan tiga orang lansia mengatakan sulit untuk mengawali tidur pada malam hari, sering pusing, mudah marah dan sulit untuk berkonsentrasi

pendekatan cross sectional yaitu memaparkan peristiwa yang terjadi pada masa kini, variabel sebab atau resiko dan akibat atau kasus yang terjadi pada objek penelitian diukur dan dikumpulkan secara simultan, sesaat atau satu kali saja dalam satu kali waktu (dalam waktu yang bersamaan), dan tidak ada follow up (Dharma Kusuma Kelana, 2014)

\section{HASIL DAN PEMBAHASAN}

a. Kualitas tidur pada lansia

Tabel. Distribusi frekuensi kualitas tidur pada lansia di Unit pelayanan sosial lanjut usia Pucang Gading Kota Semarang

\begin{tabular}{lcc}
\hline \multicolumn{1}{c}{ Kualitas tidur } & Frekuensi & $\begin{array}{c}\text { Persentase } \\
(\%)\end{array}$ \\
\hline kualitas baik & 22 & 45.8 \\
kualitas buruk & 26 & 54.2 \\
\hline Total & 48 & 100.0 \\
\hline
\end{tabular}


b. Peningkatan tekanan darah

Tabel. Distribusi frekuensi kualitas tidur pada lansia di Unit pelayanan sosial lanjut usia Pucang Gading Kota Semarang

\begin{tabular}{lcc}
\hline $\begin{array}{c}\text { Peningkatan tekanan } \\
\text { darah }\end{array}$ & Frekuensi & $\begin{array}{c}\text { Persentase } \\
(\%)\end{array}$ \\
\hline Normal & 5 & 10.4 \\
Pre hipertensi & 20 & 41.7 \\
Hipertensi & 23 & 47.9 \\
\hline Total & 48 & 100.0 \\
\hline
\end{tabular}

c. Hubungan antara kualitas tidur dengan peningkatan tekanan darah

Tabel Hubungan antara kualitas tidur dengan peningkatan tekanan darah di Unit pelayanan sosial lanjut usia Pucang Gading Kota Semarang.

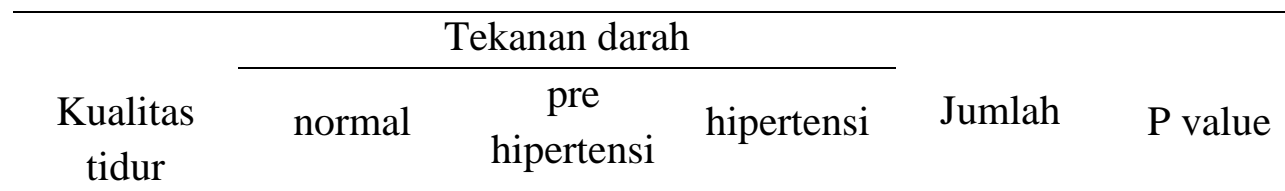

\begin{tabular}{llllllllll} 
& F & $\%$ & $\mathrm{~F}$ & $\%$ & $\mathrm{~F}$ & $\%$ & $\mathrm{f}$ & $\%$ & \\
\hline Baik & 4 & 18,2 & 14 & 63,6 & 4 & 18,2 & 22 & 100 & 0,001 \\
Buruk & 1 & 3,8 & 6 & 23,1 & 19 & 73,1 & 26 & 100 & \\
\hline Total & 5 & 10,4 & 20 & 41,7 & 23 & 47,9 & 48 & 100 &
\end{tabular}

\section{PEMBAHASAN}

Ada beberapa faktor risiko
yang menimbulkan terjadinya hipertensi antara lain genetik, jenis kelamin, umur, diet, obesitas, gaya hidup seperti merokok dan konsumsi alkohol. Hipertensi seringkali tidak menimbulkan adanya suatu gejala tertentu pada penderitanya, sehingga banyak dari penderita hipertensi baru sadar terkena penyakit tersebut ketika telah menimbulkan berbagai gangguan organ seperti gangguan fungsi jantung atau stroke. Tidak sedikit bahwa hipertensi ditemukan secara tidak sengaja ketika dilakukan suatu pemeriksaan kesehatan rutin. Hipertensi umumnya dijuluki dengan "The Silent Killer". Beberapa hasil penelitian menyebutkan bahwa semakin tinggi 
tekanan darah, semakin tinggi pula risiko penyakit kardiovaskular, stroke, dan serangan jantung .

Kualitas tidur yang buruk, selain berpengaruh pada naiknya tekanan darah juga dapat mempengaruhi status kesehatan jangka panjang seperti meningkatnya indeks masa tubuh dan depresi pada orang dewasa (Shittu, 2016). Selain berpengaruh pada tekanan darah, IMT, dan depresi, kualitas tidur yang buruk juga dapat berpengaruh terhadap kualitas hidup seseorang serta berhubungan dengan meningkatnya mortalitas. Orang yang tidur antara 7 sampai 8 jam pada malam hari, memiliki angka mortalitas terendah.

Kebutuhan tidur pada manusia bergantung pada tingkat perkembangan. Kualitas tidur lansia (60 tahun ke atas) membutuhkan waktu tidur 6 jam/ hari. ${ }^{[23]}$ Tekanan darah dipengaruhi oleh sistem secara otonom, yakni simpatis dan parasimpatis. Pada orang yang kualitas tidurnya buruk, didapatkan peningkatan aktivitas simpatis dan penurunan aktivitas parasimpatis [24]. Menurut Gangwisch, selama terjadi ketidakseimbangan pada homeostasis tubuh, sistem saraf simpatik mengaktifkan dua sistem utama dalam sistem endokrin ${ }^{[24]}$.

Hasil penelitian ini sejalan edegan penelitian Wahid 2018 tentang hubungan kualitas tidur dengan tekanan darah pasien hipertensi di Puskesmas Mojolangu Kota Malang. Hasil penelitian menunjukkan mayoritas responden dengan tekanan darah tidak normal sebanyak 53,3\% berjenis kelamin perempuan, 43,3\% berada dalam kelompok umur 41-60 tahun, 66,7\% dengan kualitas tidur buruk. Ada hubungan antara kualitas tidur dengan tekanan darah pada pasien hipertensi dengan kuat hubungan 0,649 .

Dari 48 responden 1 responden dengan tekanan darah normal memiliki kualitas tidur buruk. Kualitas tidur buruk bisa di sebabkan bukan hanya karena hipertensi tetapi bisa karena beberapa faktor yaitu lingkungan yang tidak mendukung, stress dan pekerjaan. Dari 48 responden 4 responden yang mengalami hipertensi memiliki kualitas tidur baik. Hipertensi bisa di sebabkan bukan hanya karena kualitas tidur yang buruk tetapi bisa karena beberapa faktor yaitu usia, keturunan, pola makan 


\section{KESIMPULAN}

Sebagian besar responden yang memiliki kualitas tidur buruk akan memiliki kenaikan tekanan darah, sehingga perlu dilakukan penyuluhan dan pendampingan pada penderita hipertensi.

\section{UCAPAN TERIMA KASIH}

1. Ketua STIKes Karya Husada Semarang yang telah memberikan kesempatan untuk melakukan kegiatan Penelitian sebagai bentuk pelaksanaan Tri Dharma Perguruan Tinggi

2. Keluarga tercinta yang telah senantiasa memberikan semangat

\section{DAFTAR PUSTAKA}

Azizah, M. Lilik. (2011). Keperawatan Lanjut Usia. Edisi I. Yogyakarta: Graha Ilmu.

Triyanto, Endang. (2014). Pelayanan Keperawatan Bagi Penderita Hipertensi Secara Terpadu. Yogyakarta: Graha Ilmu.

WHO. (2014). Global target 6 : A $25 \%$ relative reduction in the prevalence of raised blood pressure or contain the prevalence of raised blood pressure, according to national circumstances. Jenewa: World Health Organization.

Dinkes. (2012). Profil Kesehatan. http://www.depkes.go.id/.
Riskesdas. (2013). Riset Kesehatan Dasar. Alvailable From URL: http://riskesdas.litbang.depkes.go.id.

Ardiansyah. (2012). Medikal Bedah Untuk Mahaiswa. Jogjakarta: DIVA Press.

Wratsongko, Madyo. (2014). Shalat Jadi Obat. Jakarta: Elex Media Komputindo.

Sangiran. (2012). Mukjizat Gerakan Shalat. Jakarta: Qultum Media.

Palmer, A. (2012). Tekanan Darah Tinggi. Jakarta: Erlangga.

Muhammadun, A. S. (2010). Hidup Bersama Hipertensi. Yogyakarta: InBooks.

Muhadi. (2016). ANALISIS WHO : Evidence-based guideline. Klasifikkasi Pasien Hipertensi Dewasa.

Suprapto, Ira Haruyani. (2014). Menu Ampuh atasi Hipertensi. Yogyakarta : Notebook.

Suiraoka. (2012). Penyakit Degeneratif; Mengenal, Mencegah dan Mengurangi Faktor Risiko 9 Penyakit Degeneratif. Yogyakarta: Nuha Medika.

Susanto. (2010). Hindari Hipertensi, Konsumsi Garam 1 Sendok Per Hari. Jakarta: Gramedia.

[Muhadi. (2016). ANALISIS JNC 8 : Evidence-based guideline. Penanganan Pasien Hipertensi Dewasa.

Smeltzer,\& Bare. (2010). Buku Ajar Keperawatan Medikal Bedah Brunner \& Suddarth (Edisi 8 volume 2). Jakarta : EGC. 
Yasmine. (2013). Tekanan Darah Tinggi. Jakarta: Erlangga

Wratsongko, Madyo. (2014). Shalat jadi obat. Jakarta: Elex Media Komputindo.

Sherwood, Lauralee. (2011). Fisiologi manusia. Jakarta: EGC

Stanley, M. \& Beare, P, G. (2013). Buku Ajar Keperawatan Gerontik, Jakarta : EGC.

Buysse, D. Et al. The Pittsburgh sleep quality indeks : A new instrumen for psychiatric practice and research. Psyciatric research. Ireland : Elsevier Scientific Publisher. 1998 